\title{
1 Cold tolerance of the montane Sierra leaf beetle, Chrysomela aeneicollis
}

3 Evelyn C. Boychuk ${ }^{1,2}$, John T. Smiley ${ }^{2}$, Elizabeth P. Dahlhoff ${ }^{2,3}$, Mark A. Bernards ${ }^{1}$, Nathan E.

$4 \quad$ Rank $^{2,4} \&$ Brent J Sinclair ${ }^{1} *$

5

$6{ }^{1}$ Department of Biology, The University of Western Ontario, London, ON, Canada N6A 5B7

$7 \quad{ }^{2}$ White Mountain Research Center, 3000 E. Line Street, Bishop CA 93514

$8 \quad{ }^{3}$ Department of Biology, Santa Clara University, Santa Clara, CA 95053

$9 \quad{ }^{4}$ Department of Biology, Sonoma State University, Rohnert Park CA 94928

10 *Corresponding Author: Department of Biology, The University of Western Ontario, London,

11 ON, Canada N6A 5B7. Tel 519-661-2111x83138; fax 519-661-3935; email bsincla7@uwo.ca 


\section{Abstract}

15 Small ectothermic animals living at high altitude in temperate latitudes are vulnerable to lethal cold throughout the year. Here we investigated the cold tolerance of the leaf beetle Chrysomela

17 aeneicollis living at high elevation in California's Sierra Nevada mountains. These insects spend 18 over half their life cycle overwintering, and may therefore be vulnerable to winter cold, and prior

19 studies have demonstrated that survival is reduced by exposure to summertime cold. We identify 20 overwintering microhabitat of this insect, describe cold tolerance strategies in all life stages, and 21 use microclimate data to determine the importance of snow cover and microhabitat buffering for 22 overwinter survival. Cold tolerance varies among life history stages and is typically correlated 23 with microhabitat temperature: cold hardiness is lowest in chill-susceptible larvae, and highest in

24 freeze-tolerant adults. Hemolymph osmolality is higher in quiescent (overwintering) than 25 summer adults, primarily, but not exclusively, due to elevated hemolymph glycerol. In nature, 26 adult beetles overwinter primarily in leaf litter and suffer high mortality if early, unseasonable 27 cold prevents them from entering this refuge. These data suggest that cold tolerance is tightly 28 linked to life history stage. Thus, population persistence of montane insects may become 29 problematic as climate becomes more unpredictable and climate change uncouples the 30 phenology of cold tolerance and development from the timing of extreme cold events.

32 Key Words: Chrysomelidae; cryoprotectant; freeze tolerance; egg; larva; pupa; glycerol; alpine; 33 snow cover 
35 Montane habitats impose a range of environmental stresses on the organisms that inhabit them, 36 including high ultraviolet radiation and insolation that cause high daytime body temperatures in 37 exposed habitats, and low atmospheric pressure that cause desiccation stress and hypoxia 38 (Sømme, 1989). In these high elevation habitats, low environmental temperatures occur year39 round and winter temperatures may be especially cold, even at low latitude (Sømme, 1995). 40 Environmental cold may have significant impacts on small ectotherms such as insects, affecting 41 activity and growth, and causing mortality both through the action of cold on cells and

42 molecules, and because of the likelihood of internal ice formation (Harrison et al., 2012).

43 Prolonged exposure of montane insects to sub-zero temperatures may lead to overwintering 44 mortality and sub-lethal reduction of fitness characters, like growth and reproductive output 45 (Sinclair et al., 2003). Unfortunately, the physiology of cold tolerance in montane insects has 46 been incompletely explored (e.g. Kohshima, 1984; Sinclair and Chown, 2005; Sømme, 1989;

47 Vrba et al., 2012; Wharton, 2011; Zettel and Zettel, 1994), especially in the mountains of the 48 Americas (but see Edwards, 1986; Ring, 1982; Sømme et al., 1996).

Low temperatures experienced by montane insects may be particularly influenced by the

51 duration and depth of snow cover. Paradoxically, extreme low temperatures and freeze-thaw

52 cycles are more common in montane habitats during climatically-warm winters, which often lack

53 significant snowfall relative to cooler, wetter winters, during which accumulated snow cover

54 provides significant insulation to overwintering insects (e.g. Sinclair, 2001b). Interactions

55 between snow cover and extreme low temperature can be especially important in spring and

56 autumn, when early accumulation or late melt of snow cover can extend the period during which 
57 environmental temperatures are buffered. In contrast, a reduced snow pack can expose

58 overwintering organisms to extreme low temperatures in the spring and autumn, at times and/or

59 life stages when the insect's cold tolerance may be inadequate for survival through the episode

60 (Williams et al., 2015). Predicted winter climate change, with modified temperature and

61 precipitation regimes, may therefore have a substantial impact on montane insects by modifying

62 both the occurrence and intensity of cold exposure (Gu et al., 2008; Williams et al., 2015). Thus,

63 understanding mechanisms of cold tolerance, and how it varies through the life history of an

64 animal, is essential for understanding the potential impacts of climate change on organisms in

65 montane environments.

67 Cold-hardy insects primarily use one of two strategies to survive low temperatures; they either withstand the formation of internal ice (freeze tolerance), or depress their supercooling point

69 (SCP, the temperature at which they freeze) to remain unfrozen at low temperatures (freeze

70 avoidance). Many insects, however, are killed by cold at temperatures where they remain

71 unfrozen, and these are termed chill-susceptible (Lee, 2010). The biochemistry associated with

72 insect cold tolerance is fairly well-described. Briefly, low molecular weight cryoprotectants (for

73 example, polyols such as glycerol or sugars such as trehalose) can protect cells and membranes

74 against the osmotic dehydration associated with freeze tolerance or colligatively depress the SCP

75 in freeze avoidant insects. Improvements in cold tolerance have been associated with even small

76 (10-100 mM) increases in the concentration of cryoprotectants (Lee et al., 1987), although the

77 mechanisms of this protection are less well-understood (see MacMillan et al., 2015, for a

78 possible relationship with water balance in the cold). Thermal hysteresis agents (including

79 antifreeze proteins and glycolipids) inhibit recrystallization in freeze-tolerant species, or retard 
nucleation in freeze-avoidant insects (Walters et al., 2011; Zachariassen and Kristiansen, 2000).

81 Finally, control of ice nucleation is a key difference between strategies, with freeze tolerant

82 species generally initiating ice formation at consistently high (above $-10{ }^{\circ} \mathrm{C}$ ) sub-zero

83 temperatures (Sinclair et al., 2009).

85 Most species of temperate insects have a specific life history stage in which they overwinter. Not 86 surprisingly, insects are usually most cold tolerant during these overwintering stages, developing

87 cold tolerance during the autumn (or during diapause development) and losing it upon

88 resumption of activity in the spring (Lee, 2010). Not all overwintering insects must develop

89 extreme cold tolerance. For example, larvae of acorn weevils have limited cold tolerance, but 90 overwinter successfully in Southern Canada by relying on the buffering effect of being buried in

91 the soil (Udaka and Sinclair, 2014). This is in contrast to species that are exposed to near-

92 ambient temperatures in unprotected, above-snow, wintering microsites, like goldenrod gall flies,

93 which have evolved robust strategies of freeze tolerance (Irwin and Lee, 2003). The high degree

94 of plasticity of cold tolerance among different life history stages and among species suggests

95 energetic and evolutionary trade-offs in cold tolerance strategy and capacity (see also Sinclair,

96 1999; Sinclair and Chown, 2010; Voituron et al., 2002; Zachariassen, 1985). Thus,

97 understanding how cold tolerance changes among life stages and seasons is critical to

98 understanding the constraints on cold tolerance. Unfortunately, there are surprisingly few studies

99 of cold tolerance in montane insects that investigate cold tolerance of all life history stages, even

100 those that provide year-round comparisons (e.g. Ramløv, 1999; Ramløv et al., 1992; Sinclair, 101 1997). 
103 In this study, we investigate cold tolerance in the leaf beetle Chrysomela aeneicollis, an ideal 104 species in which to investigate cold tolerance of montane species. This beetle lives on willows 105 along streams, lakes, and bogs throughout Western North America (Brown, 1956; Dellicour et 106 al., 2014); at the southern edge of their range in the southern Sierra Nevada Mountains of Eastern 107 California at high elevation (2800-3200 m). Sierra willow beetles overwinter as adults, emerging 108 from winter diapause in mid-May and completing a single cycle of reproduction and larval 109 development during the summer. Adults mate and females lay eggs in June, eggs hatch and 110 larvae mature through three instars in July and August, pupating in August and September. 111 Newly-eclosed adults feed in August and September, before entering a winter quiescence (or 112 possibly diapause) in early October (Smiley and Rank, 1986). Beetles living in high elevation 113 habitats in the Sierra Nevada are challenged by exposure to potentially-lethal cold temperatures 114 throughout the year. We have observed: 1) cold mortality in adults emerging from diapause after 115 a single night time cold exposure to temperatures between -8 and $-10{ }^{\circ} \mathrm{C}$ in June (Bruce, 2005; 116 Dahlhoff and Rank, 2007); 2) cold-induced mortality in first- and second-instar larvae during 117 exposure to temperatures between -4 and $-6^{\circ} \mathrm{C}$ in July (McMillan et al., 2005; Smiley and Rank, 118 1986); and 3) high mortality of pupae due to a single early frost in October (present study).

119 Furthermore, long-term field observations of Sierra willow beetle populations show that 120 abundance declines precipitously after extremely cold winters. For example, there was virtually 121 no snowpack at most mid- and low-elevation sites in 2007, and beetle populations declined by 80 $122 \%$ in the subsequent year, especially at mid- and low elevation localities (Smiley, Dahlhoff and 123 Rank, unpublished observations). Thus, it appears that cold tolerance may be important year124 round in C. aeneicollis. 
126

127

128

129

130

131

132

133

134

135

136

137

138

139

140

141

142

143

144

145

146

\section{Material and Methods}

\subsection{Study animals}

We hand-collected Chrysomela aeneicollis adults and larvae from willow (primarily the Sierra willow Salix orestera) during the summer at sites around $3200 \mathrm{~m}$ elevation from three study drainages in the Eastern Sierra Nevada mountains of California, which have been well-described (e.g. Dahlhoff et al., 2008; Dahlhoff and Rank, 2000; Rank, 1992a): Big Pine Creek (BPC), Bishop Creek (BC) and Rock Creek (RC). We did not examine the well-described polymorphism at the glycolytic enzyme phosphoglucose isomerase (PGI) described in earlier studies (Dahlhoff and Rank, 2007; Rank, 1992a; Wheat and Hill, 2014), and preliminary experiments did not indicate significant differences in supercooling points of larvae or adults among drainages, so individuals from different drainages were pooled for all experiments. Eggs and first instar larvae were collected as full clutches by plucking the whole leaf on which the clutch was laid; no more than two individuals per clutch were used in any experiment. All other life stages were collected as individuals from willow leaves and returned in an insulated backpack within $12 \mathrm{~h}$ to the Owens Valley Laboratory of University of California’s White Mountain Research Center (Bishop, CA), where all experiments were conducted. Beetles were maintained in groups of approximately 100 individuals in 5 litre plastic containers at $20^{\circ} \mathrm{C}, 12 \mathrm{~h} \mathrm{D}: 4^{\circ} \mathrm{C}, 12 \mathrm{~h} \mathrm{~N}(20 \mathrm{~min}$ ramp-up and -down time) inside an incubator (Percival, Perry, IA, USA). Beetles were fed on a diet of fresh Salix orestera collected from $3000 \mathrm{~m}$ in Bishop Creek every 2-3 days. After laboratory manipulation, individuals used for later biochemical analysis were placed in $0.6 \mathrm{~mL}$ microcentrifuge tubes and frozen at $-80{ }^{\circ} \mathrm{C}$. 
148 Summer adults, eggs and first instar larvae were collected and frozen for future analyses between 149 July and August 2011. Second instar larvae, third instar larvae, pupae and newly-eclosed adults were collected and frozen between July and August 2012. Quiescent beetles were obtained either

151 as field-collected pupae or newly-eclosed adult beetles and shipped to University of Western

152 Ontario. Adult beetles were reared in $40 \times 30 \times 40 \mathrm{~cm}$ clear plastic cages with a mesh top for 153 ventilation and were provided with Salix amygdaloides for food. Salix amygdaloides is similar to 154 S. orestera in that it has a high salicylate content that is preferred by C. aeneicollis (Rank, 155 1992b). In all cases, willow was changed 2-3 times per week, misted with water daily, and water 156 provided ad libitum via cotton-stoppered vials of water. The plastic cages were kept in a walk-in 157 controlled-climate chamber in the Biotron Institute for Experimental Climate Change Research 158 (University of Western Ontario) at $20^{\circ} \mathrm{C}, 12 \mathrm{~h} \mathrm{D}: 4^{\circ} \mathrm{C}, 12 \mathrm{~h}$ N. Quiescence was induced in newly159 eclosed adult beetles brought to the University of Western Ontario by low temperature 160 acclimation $\left(4^{\circ} \mathrm{C}\right.$ in complete darkness for at least two weeks) starting in September.

161 Overwintering adult beetles were kept in the dark at $0.5^{\circ} \mathrm{C}$ in $30 \mathrm{~mL}$ translucent plastic cups 162 (Solo, Lake Forest, IL, USA), with a small piece of moist paper towel. Adults with reduced 163 movement in response to stimulus at room temperature with blunt forceps were classified as 164 'quiescent'. Willow branches and/or paper towels were changed and moistened weekly.

\subsection{Overwintering site and field observations}

167 To determine the overwintering microsite of $C$. aeneicollis, we enclosed an entire $1 \mathrm{~m}$ tall $S$. 168 orestera plant, plus several potential overwintering microhabitats (a $30 \mathrm{~cm}$ pile of rocks and a $1691.5 \mathrm{~m}$ long, $10 \mathrm{~cm}$ diameter rotting pine (Pinus murrayana) branch) in a large, chemically170 untreated mosquito net (Mombasa Outback double travel net, REI, Sumner, WA) with the edges 
171 partially buried and held down with stones. This experimental plot was located at $3200 \mathrm{~m}$

172 elevation in the Green Lake sub-drainage of Bishop Creek $\left(37^{\circ} 10^{\prime} 41^{\prime \prime} \mathrm{N} ; 118^{\circ} 33^{\prime} 5^{\prime}\right.$ W). In mid-

173 September 2011, we placed ca. 200 freshly collected beetles (a mix of larvae, pupae and newly-

174 emerged adults) inside the net (approximately ten beetles were already on the plant). We

175 collected samples at the beginning of November, when no beetles were visible on the leaves of

176 willow plants. We separately collected the net, the dried leaves still in the willow canopy, the

177 soil beneath the rock pile, the leaf litter above, under $(<0.1 \mathrm{~m})$, near (between $0.5 \mathrm{~m}$ and $1 \mathrm{~m})$ and

178 away $(>1 \mathrm{~m}$ ) from the base of the plant, and the loose soil under, near and away from the base of

179 the plant, down to $20 \mathrm{~cm}$ depth. The log was broken up and searched for beetles on site. The bags

180 were returned to the laboratory at White Mountain Research Station, where they were kept in the 181 warm, lighted lab and hand-searched for live beetles for several days. An unseasonable early 182 snow occurred in October 2011 caused significant mortality of juveniles. Before and after that 183 event, beetles were censused at, and collected from, a number of sites in each drainage area, and 184 mortality rates calculated.

\subsection{Cold tolerance}

187 We determined cold tolerance strategy, supercooling point (SCP, the temperature at which ice 188 formation begins), and median and lower lethal temperatures for acute cold exposures (highest 189 temperatures that kill $50 \%\left[\mathrm{LT}_{50}\right]$ and $100 \%$ [LLT] of individuals, respectively) for eggs, all 190 three larval instars, pupae, and adults. We also measured survival of prolonged cold exposure in 191 quiescent adults. Cold exposures were conducted with individuals placed in $0.6 \mathrm{~mL}$

192 microcentrifuge tubes in contact with a 36 AWG type-T thermocouple interfaced to a computer 193 via a TC-08 thermocouple interface (Pico Technology, Cambridge, UK). First-instar larvae and 
eggs were affixed to the thermocouple using a thin layer of silicone grease; other stages were

195

held in place in the microcentrifuge tube with a piece of cotton wool. Microcentrifuge tubes were placed in wells drilled in an aluminium block cooled by methanol circulated from a Lauda Proline 855C refrigerated circulator (Lauda, Würzburg, Germany).

To determine the cold tolerance strategy, we used data from the $\mathrm{LT}_{50}$ and SCP experiments to determine whether individual animals froze and whether they survived that internal ice formation (see also Crosthwaite et al., 2011; Sinclair and Chown, 2005). If individuals were killed by cold when freezing did not occur, that stage was considered chill susceptible; if only individuals that froze were killed at a given temperature, we deemed them freeze avoidant; and if individuals that experienced internal ice formation survived, we considered them freeze tolerant.

\section{To measure supercooling points, individuals were equilibrated at $0{ }^{\circ} \mathrm{C}$ for $10 \mathrm{~min}$, then cooled} from 0 to $-30{ }^{\circ} \mathrm{C}$ at $0.5^{\circ} \mathrm{C} \cdot \mathrm{min}^{-1}$. The SCP was the lowest temperature recorded before the exotherm associated with internal ice formation (e.g. Figure 1). LLT and $\mathrm{LT}_{50}$ were assessed according to the approach of Sinclair \& Chown (2005). Briefly, eight beetles at a time were held at $0^{\circ} \mathrm{C}$ for an equilibration period of $10 \mathrm{~min}$ before being cooled at $0.1{ }^{\circ} \mathrm{C} \cdot \mathrm{min}^{-1}$ to a test temperature, where they were held for $1 \mathrm{~h}$, prior to being rewarmed at $0.5^{\circ} \mathrm{C} \cdot \mathrm{min}^{-1}$ to $0{ }^{\circ} \mathrm{C}$. Four to six test temperatures were used for each life stage, with $0{ }^{\circ} \mathrm{C}$ at the upper temperature end, and temperatures evenly spaced to -40 (eggs) $,-9,-10,-12\left(1^{\text {st }}, 2^{\text {nd }}\right.$ and $3^{\text {rd }}$ instar larvae, respectively), -20 (pupae), -15 , and $-30{ }^{\circ} \mathrm{C}$ (summer and quiescent adults, respectively). After rewarming, beetles were placed individually in the wells of a 6 -well tissue culture plate at $+4{ }^{\circ} \mathrm{C}$ with a moist paper towel, and survival assessed. Adults and larvae- coordinated movement after $24 \mathrm{~h}$; eggs- 
217 successful hatching; pupae- response to mechanical stimulus. A handling control was also used,

218 wherein individuals were placed in the wells of 6 -well tissue culture plate at $+4{ }^{\circ} \mathrm{C}$ with a moist 219 paper towel and survival monitored after $24 \mathrm{~h}$.

221 To determine survival of prolonged periods of internal ice formation by quiescent adults, four 222 quiescent adults were exposed to $-8{ }^{\circ} \mathrm{C}$ for each of $1,4,6$, or $12 \mathrm{~h}$. Individuals were cooled at 0.1

$223{ }^{\circ} \mathrm{C} \cdot \mathrm{min}^{-1}$ (as above), and survival assessed after $24 \mathrm{~h}$ at $4{ }^{\circ} \mathrm{C}$. A control group of four individuals 224 were held at $-4{ }^{\circ} \mathrm{C}$ (a temperature at which they do not freeze) for $12 \mathrm{~h}$, and survival assessed 225 after $24 \mathrm{~h}$.

227 We compared supercooling points among life stages and seasons using a one-way ANOVA 228 followed by Tukey's post hoc tests in R version 2.15.1 (R Core Team, 2012). We fitted 229 generalized linear models to survival data (binomial error, logit link; using R) and used this to 230 calculate the $\mathrm{LT}_{50}$ (the temperature at which $50 \%$ of beetles were killed), as well as the $\mathrm{LT}_{5}$ and $231 \mathrm{LT}_{95}$. We used a lack of overlap of these intervals to identify differences in $\mathrm{LT}_{50}$ among life 232 stages and seasons.

\subsection{Cryoprotectants}

235 We collected a representative sample from each life stage in 2011 and 2012 to determine the 236 identity and concentration of cryoprotectants. Gas chromatography (GC) was used to identify 237 low molecular-weight cryoprotectants present in homogenized whole individuals. Because 238 glycerol was the dominant cryoprotectant, its concentration was measured in a higher-throughput 
239 spectrophotometric assay (Crosthwaite et al., 2011). Haemolymph osmolality and thermal

240 hysteresis activity were measured using nanolitre osmometry (cf. Sinclair and Chown, 2002).

241 Individual beetles were killed in liquid nitrogen vapour, weighed (fresh mass), dried $\left(70{ }^{\circ} \mathrm{C}, 4 \mathrm{~d}\right.$ )

242 and reweighed (dry mass), and total water content determined as the difference between fresh

243 and dry mass.

245 Cryoprotectants were identified by gas chromatography of their alditol acetate derivatives, using 246 methods derived from Blakeney et al. (1983) and described by Crosthwaite et al. (2011). Briefly, 247 individuals were homogenized in distilled, deionized water (100 $\mu \mathrm{L}$ for individuals <20 mg, 200 $248 \mu \mathrm{L}$ for individuals $>20 \mathrm{mg}$ ), heated for $20 \mathrm{~min}$ at $100{ }^{\circ} \mathrm{C}$ to denature proteins and centrifuged at $24925000 \times g$. Lipids were removed from the supernatant by removing the aqueous layer after 250 addition of sulphuric acid $(0.1 \mathrm{M}, 0.7 \mathrm{~mL})$ and then hexane $(2 \mathrm{~mL})$. An aliquot of this aqueous 251 layer $(0.1 \mathrm{~mL})$ was then neutralized with ammonium hydroxide and an internal standard $(50 \mu \mathrm{L}$ 252 xylitol, $1 \mathrm{mg} / \mathrm{mL}$ in $1 \mathrm{M}$ ammonia) added. Monosaccharides were reduced to polyhydric alcohols 253 by incubation at $40{ }^{\circ} \mathrm{C}(90 \mathrm{~min})$ after the addition of $1 \mathrm{~mL} 2 \% \mathrm{w} / \mathrm{v}$ sodium borohydride in 254 DMSO. Excess sodium borohydride was decomposed after cooling to room temperature by the 255 addition of $0.1 \mathrm{~mL}$ glacial acetic acid. The reduced sugars were then acetylated by addition of $256 \quad 0.2 \mathrm{~mL} \mathrm{1-methylimidazole} \mathrm{(as} \mathrm{a} \mathrm{catalyst)} \mathrm{followed} \mathrm{by} \mathrm{acetic} \mathrm{anhydride}(2 \mathrm{~mL})$ for $10 \mathrm{~min}$ at 257 room temperature. After addition of distilled deionised water to decompose excess acetic 258 anhydride, the sample was mixed with dichloromethane $(1 \mathrm{~mL})$ and an aliquot of the 259 dichloromethane layer dried under nitrogen and re-suspended in $0.2 \mathrm{~mL}$ dichloromethane to 260 concentrate the sample. Samples not analysed immediately were stored at $-20{ }^{\circ} \mathrm{C}$. 
262 Derivitised samples were identified by capillary gas chromatography with flame ionization

263 detection (Agilent 7890, Agilent Technologies, Santa Clara, CA, USA) using a CP-Sil 88,

264 WCOT fused silica, $25 \mathrm{~m}$ x $0.25 \mathrm{~mm}$ i.d. column (Varian, Palo Alto, CA, USA) with nitrogen as

265 a carrier gas, an injector temperature of $250{ }^{\circ} \mathrm{C}$ and an FID temperature of $300{ }^{\circ} \mathrm{C}$. Samples $(1$

$266 \mu \mathrm{L}$ ) were injected in splitless mode at an initial column temperature of $140{ }^{\circ} \mathrm{C}$, and eluted as

267 follows: $140{ }^{\circ} \mathrm{C}$ held for 5 minutes, followed by a ramp to $230{ }^{\circ} \mathrm{C}$ at $4{ }^{\circ} \mathrm{C} / \mathrm{min}, 15$ minutes

268 isothermal at $230{ }^{\circ} \mathrm{C}$ and a final ramp to $240{ }^{\circ} \mathrm{C}$ at $10{ }^{\circ} \mathrm{C} / \mathrm{min}$. The final temperature was held for

2696.5 minutes. Compounds were identified by comparison of retention times with a mix of known

270 standards, and quantified by comparison to a calibration curve constructed for authentic

271 standards prepared by the same procedure as above.

273 To measure glycerol content spectrophotometrically (see also Crosthwaite et al., 2011), whole

274 beetles were homogenized in $0.05 \% \mathrm{v} / \mathrm{v}$ Tween 20 in water and incubated with free glycerol

275 reagent (Sigma Aldrich, Inc., St Louis, MO, USA) at room temperature $\left(22{ }^{\circ} \mathrm{C}\right)$ for five minutes.

276 Following incubation, absorbance at $540 \mathrm{~nm}$ was read on a microplate spectrophotometer

277 (SpectraMax 340PC, Molecular Devices, Sunnyvale, CA, USA) and glycerol content calculated

278 by comparison with a standard curve. Glycerol content per individual was corrected to mass and

279 average water content for the life stage (measured in additional individuals) to estimate

280 concentration, assuming equal intracellular and extracellular concentration. Glucose

281 concentration was measured spectrophotometrically using methods described by Marshall and

282 Sinclair (2010). Haemolymph osmolality and thermal hysteresis were measured using a nanolitre

283 osmometer (Clifton Technical Physics, Hartford, NY, USA), according to the methods of

284 Sinclair \& Chown (2002). The abdomen of adult beetles was pierced with a clean dissection pin, 
285 and the resulting droplet of hemolymph was stored frozen at $-80{ }^{\circ} \mathrm{C}$ under type $\mathrm{B}$ immersion oil

286 (cat. no. 16484, Cargille Laboratories, Cedar Grove, NJ, USA) to minimize oxidation and

287 evaporation. We determined the melting point (and therefore the osmolality) of the hemolymph,

288 the difference between the melting and freezing point (thermal hysteresis) and observed ice

289 crystal morphology (angular ice crystals, or those with distinctly flat edges are indicative of

290 antifreeze protein activity (Zachariassen and Kristiansen, 2000)).

291

292 We compared glycerol content and water content among life stages and seasons in R using an

293 ANCOVA with body mass as a covariate followed by a Tukey's post-hoc test. We compared

294 (estimated) glycerol concentration, osmolality, and thermal hysteresis among life stages and/or

295 seasons using Welch's t-tests, or ANOVA, followed by a Tukey's post hoc test, also in R.

\subsection{Microclimate temperature recordings}

298 Microclimate temperature data were collected at 30 min intervals year-round at six sites (Table

299 1) in the Sierra Nevada Mountains using HOBO Pendant UA-002-08 data loggers (Onset

300 Computer Corporation, Bourne, MA, USA). The data loggers were deployed in sets of three on 301 the same willow plant: mid-willow (shielded inside a white plastic cup hanging upside down ca.

$3021.2 \mathrm{~m}$ above the ground, indicative of the canopy under-leaf temperatures the beetles experience

303 when feeding; note that the willows may collapse under the weight of snow in the winter,

304 reducing the height above the ground considerably), at the base of the willow stem, and buried

305 ca. $5 \mathrm{~cm}$ in the soil next to the roots of the willow. The mid-willow data loggers were deployed

306 during the summer of 2000 and the base-of-the-willow and soil loggers were deployed in the 
summer of 2009. To assess the relationship between recorded logger temperatures and

308

snowpack, we analysed data from a snow sensor used by the California Department of Water Resources at 3108 meters in the Bishop Creek catchment, using data available to the public (California Data Exchange Center; ca.gov), and compared that data with those from a pendent logger deployed at the base of the willow, about 500 meters from the weather station.

Using these microhabitat temperature data and published observations of phenology for each life stage (e.g. Rank, 1994) we defined the span of dates that could plausibly be experienced by each life stage, and constrained our analysis of each stage's cold tolerance to those periods. Within each period, for each life stage, we identified cold events that crossed the $\mathrm{LT}_{50}$ threshold for each life stage during the time of the year that they are present using R code based on Marshall and Sinclair (2012b) and Sinclair (2001a).

\section{Results}

\subsection{Field observations}

Fifty-one live adult beetles were recovered from the overwintering cage in November. The majority of the beetles were present in the soil below the leaf litter (ca. $20 \mathrm{~cm} \mathrm{depth):} 22$ were found within $0.5 \mathrm{~m}$ of the base of the plant, 6 at $0.5-1 \mathrm{~m}$, and $8>1 \mathrm{~m}$ from the base of the plant. Fourteen beetles were found in leaf litter directly at the base of the plant, whereas no beetles were present in leaf litter away from the plant. One beetle was observed on the above-ground portion of the willow, none were beneath stones or logs. 
329 An unseasonal hard frost $\left(-14^{\circ} \mathrm{C}\right)$ during October 6-8 2011 occurred when larvae, pupae and

330 adults were still present on willow leaves. The day after this event, adult beetles were still

331 observed, but no live pupae or larvae were observed across the full range of drainages and

332 elevations occupied by C. aeneicollis (see Table S2).

$334 \quad 3.2$ Cold tolerance

335 All quiescent adult beetles and $99 \%$ of summer-collected adult beetles survived internal ice

336 formation for one hour and are therefore classified as freeze tolerant. By contrast, pupae and

337 eggs were killed by freezing, but not by cold exposure above the SCP, suggesting that they are

338 freeze avoidant. All three larval stages were killed by cold exposure at temperatures that did not

339 initiate internal ice formation, and are therefore chill-susceptible (Table 2).

341 Eggs had the lowest SCP, which was significantly lower than that of the three larval instars

342 (which did not differ significantly from one another), while adults had the highest SCP (Table 3).

343 SCPs of adults did not differ significantly between summer-collected and quiescent individuals

344 (Table 3). When frozen, 18 of 24 pupae showed double exotherms $\left(-13.6 \pm 3.2{ }^{\circ} \mathrm{C}\right.$ and $-17.5 \pm$

$3450.8^{\circ} \mathrm{C}$; Figure 1 ), while the remaining six had only a single exotherm at $-11.1 \pm 2.8^{\circ} \mathrm{C}$, which did

346 not differ significantly from the higher of the double exotherms (Table 3). Dissections showed

347 that double-exotherm pupae contained tissue moulted from the $3^{\text {rd }}$ instar larva that had not

348 completely dried. Single-exotherm pupae were later in development, and the desiccated remains

349 of the $3^{\text {rd }}$ instar cuticle no longer frozen. Early-development pupae that experienced a single

350 exotherm were killed $(n=18)$, so we infer that the first exotherm represents freezing of the 
351 developing pupal tissue, and that this first SCP is a valid measure of lethal temperature for all 352 individuals.

354 The $\mathrm{LT}_{50}$ of eggs was lower than other life stages, and there was a high variance in the $\mathrm{LT}_{50}$ of 355 pupae, with a $7^{\circ} \mathrm{C}$ difference between $\mathrm{LT}_{5}$ and $\mathrm{LT}_{95}$. Larvae had a relatively high $\mathrm{LT}_{50}$ (ranging 356 from -3.3 to $-8.7^{\circ} \mathrm{C}$ ), which did not differ significantly among instars (Table 3 ). The $\mathrm{LT}_{50}$ of 357 quiescent adults $\left(\mathrm{LT}_{50}:-15^{\circ} \mathrm{C}\right)$ were significantly more cold-tolerant than summer adults $\left(\mathrm{LT}_{50}\right.$ : $3589.2^{\circ} \mathrm{C}$; Table 3 ), although the estimated $\mathrm{LT}_{50}$ for the former is lower than the lowest temperature 359 survived by any individual quiescent beetle $\left(-10^{\circ} \mathrm{C}\right)$, which we use as an estimate of low 360 temperature tolerance for subsequent considerations. Although quiescent adults survived for one 361 hour after the initiation of ice formation when held at $-8^{\circ} \mathrm{C}$, survival decreased rapidly, with only 3626 of 8 individuals surviving four hours of freezing, 2 of 8 after $6 \mathrm{~h}$ and no beetles survived $12 \mathrm{~h}$ 363 of ice formation.

366 Hemolymph osmolality of quiescent beetles $(877 \pm 5.5 \mathrm{mOsm})$ was more than double that of 367 summer-collected beetles $\left(380 \pm 3.3 \mathrm{mOsm} ; \mathrm{t}_{8}=77.4, \mathrm{p}<0.001\right)$. Very low levels of thermal 368 hysteresis activity were observed in adult hemolymph in both summer $\left(0.08 \pm 0.004{ }^{\circ} \mathrm{C}\right)$ and 369 winter $\left(0.22 \pm 0.05^{\circ} \mathrm{C} ; \mathrm{t}_{8}=2.9, \mathrm{p}=0.020\right)$. Growing ice crystals were circular in both summer and 370 quiescent adults. Water content varied from 68 to $86 \%$, was lowest in adult beetles and eggs, 371 intermediate in the three larval instars, and highest in pupae (Figure 2). 
373 Glycerol, rhamnose, fructose and glucose were the main sugars and polyhydroxy alcohols

374 identified by gas chromatography in extracts of whole individuals (Figure 3). Gas

375 chromatography suggested that the quantity of glycerol and glucose changed significantly from

376 summer to winter (Figure 3, n=1/season). However, spectrophotometric measurement of glucose

377 concentration revealed no significant difference between quiescent $(1.4 \pm 0.18 \mathrm{mM} / \mathrm{L})$ and

378 summer-collected $(3.0 \pm 0.81 \mathrm{mM} / \mathrm{L})$ beetles $\left(\mathrm{t}_{4}=1.948, \mathrm{p}=0.123\right)$. Glycerol content and

379 estimated concentration was significantly higher in quiescent beetles than in all other life stages

380 (Figure 2).

381

382

3.4 Microclimate temperatures

383 Microclimate varied by altitude, season and among years, and was affected by snow cover 384 (Figure 4; Supplementary Material Table S1, Figures S1, S2). When significant snow cover ( 6 $385 \mathrm{~cm}$ ) was present (e.g. a few days in October 2011, plus Feb-April 2012 for one study locality), 386 air temperatures at the top of the soil were close to $0{ }^{\circ} \mathrm{C}$. However, when snow was scant or 387 absent, surface temperatures were well below or above zero. Minimum microclimate 388 temperatures were lowest in the willow canopy, with $-24.8^{\circ} \mathrm{C}$ recorded at the mid-willow logger 389 on 12 January 2007 at $11.55 \mathrm{pm}$ at the $2905 \mathrm{~m}$ "40 bog” site in Big Pine Creek. Temperatures at 390 the base of the willow were more buffered (minimum of $-13.3{ }^{\circ} \mathrm{C}$ at $3353 \mathrm{~m}$ on 5 October 2009 391 at $6.00 \mathrm{am})$, and never dropped below $-5.9{ }^{\circ} \mathrm{C}(8.30 \mathrm{am}, 6$ December 2009 at the $2773 \mathrm{~m}$ site $)$ in 392 the soil. There was considerable variation in temperature, and minimum temperatures below $0{ }^{\circ} \mathrm{C}$ 393 were recorded at the mid willow loggers almost year-round (Figure 4). Although minimum 394 temperatures at the mid-willow reached very low temperatures, we did not record any instances 395 of minimum temperatures exceeding the tolerance of the life stage(s) of $C$. aeneicollis most 
likely to be present, assuming that quiescent beetles overwinter in the soil (see above; Figure 5).

397 Microclimate temperatures at all microsites were strongly influenced by snow cover. During the

398 winter, snow cover buffered temperatures to close to $0{ }^{\circ} \mathrm{C}$ at most locations during the extent of 399 this study (Figure 4).

\section{Discussion}

Pre-adult life stages of Chrysomela aeneicollis are relatively intolerant to cold, and we report mortality of pupae in the field after an early autumn cold event. Such direct reports of

404 unseasonable cold-related mortality events are rare but have been documented in other beetles, such as the North American bark beetle Dendroctonus ponderosae (Creeden et al., 2014). We

406 also show that freeze-tolerant adults overwinter in the leaf litter and soil, where they are buffered

407 from climate extremes. However, we recorded several instances of mid-willow temperatures

408 below the beetle's $\mathrm{LT}_{50}$, and the lowest soil temperatures we recorded were at the lowest-

409 elevation site, suggesting that the buffering effect of snow cover (which is less reliable at low

410 elevations) is important for overwintering survival. This supports the hypothesis that local low

411 altitude extinctions of sub-populations of $C$. aeneicollis may have been caused by cold winter

412 temperatures at low elevations in years with little snow cover (Rank, 1994).

414 It is not usually possible to predict the cold tolerance strategy adopted by insects; many montane 415 insects are freeze tolerant (Sinclair and Chown, 2005; Sømme, 1989; Wharton, 2011), but there 416 is often little phylogenetic signal within groups (Sinclair and Chown, 2010). Among chrysomelid 417 beetles, the Colorado Potato Beetle (Leptinotarsa decemlineata), which overwinters in the soil as 
418 a diapausing adult (Lee et al., 1994), is freeze-avoidant, but there are also several species that are 419 freeze tolerant (e.g. Zachariassen et al., 2008) and chill-susceptible (e.g. Watanabe and Tanaka, $4201998,1999)$. Glycerol is accumulated as a cryoprotectant by at least one freeze-tolerant 421 chrysomelid, Melasoma collaris (Gehrken and Southon, 1997), and myo-inositol by the chill422 susceptible species (Watanabe and Tanaka, 1998, 1999). Thus, while there is a diversity of cold 423 tolerance strategies in the Chrysomelidae, freeze tolerance and glycerol accumulation in adult $C$. 424 aeneicollis is consistent with other cold-hardy species in the family.

426 The lowest temperature that adult $C$. aeneicollis survived in our experiments was $-10^{\circ} \mathrm{C}$, and 427 there was low survival of longer periods frozen, with $75 \%$ mortality after $6 \mathrm{~h}$ at $-8^{\circ} \mathrm{C}$. This may 428 reflect a reliance on the buffered habitat to prevent long exposure to cold in the field. Alternately, 429 our laboratory protocol may not have maximized the cold tolerance capabilities of this species.

430 Freeze tolerance can change during the winter season (e.g. Sinclair, 1997; Storey and Storey, 431 1983), and cold tolerance may be plastic during rapid cold-hardening (e.g. Lee et al., 2006) or in 432 response to repeated cold stress (Marshall and Sinclair, 2012a). Further experiments on the 433 plasticity of cold tolerance, or on beetles field-collected during winter are necessary to determine 434 whether we observed maximal cold tolerance for overwintering adults in this species.

436 Our data logger temperatures suggest that, with the exception of pupae late in the season, pre437 adult stages of $C$. aeneicollis are not prepared to encounter sub-zero temperatures, and prior 438 studies show that they suffer high mortality when they do so (McMillan et al., 2005).

439 Chrysomela aeneicollis eggs were freeze avoidant, (in keeping with most other insect eggs; 440 Sinclair and Chown, 2010), and were able to tolerate brief extremes of temperature, likely 
441 because of their small size and resistance to ice nucleation. Eggs are unlikely to encounter

442 extremely low temperatures, and although we did not explore tolerance to extended cold

443 exposure, we expect that eggs would have limited tolerance for this. Larvae were chill-

444 susceptible and had very limited cold tolerance. This is not surprising in a univoltine species, but

445 does potentially leave the species vulnerable to late summer cold snaps - for example, summer

446 temperatures below $-5^{\circ} \mathrm{C}$ have been recorded at Lake Louise, Alberta, at the North end of the $C$.

447 aeneicollis range (Environment Canada; climate.weather.gc.ca), and could account for the

448 northern range limit for this species (Brown, 1956). Indeed, in the Sierra, a single night-time

449 exposure to $-6^{\circ} \mathrm{C}$ in summer caused significant mortality (McMillan et al., 2005).

451 Almost all pupae in which ice formed were killed, suggesting that they are freeze-avoidant. This

452 is borne out by the mortality event we observed in the field, where overnight minima of -7 to -14

$453{ }^{\circ} \mathrm{C}$ coincided with mortality of all pupae observed at multiple sites. This event occurred at a time 454 when the majority of beetles had emerged as adults (and were therefore freeze tolerant). The 455 double exotherms we observed in some pupae in the laboratory likely derive from the freshly 456 moulted exuvium in the early stages of pupation. Double exotherms are occasionally observed in 457 freeze tolerant species (e.g. Sformo et al., 2009; Sinclair et al., 2009), and are thought to 458 represent freezing of independent compartments. In the present context, we hypothesise that the 459 pupating beetle and the exuvium freeze separately; because the first exotherm was always 460 accompanied by mortality, we propose that it represents freezing of the developing beetle. We 461 did observe survival of a small number of pupae after freezing, and hypothesise that these may 462 have been pharate adults, which we would expect to be freeze tolerant. The three different 
463 responses of 'pupae' we observed emphasise the importance of accounting for developmental

464 stage when determining insect cold tolerance, especially during pupation.

466 In keeping with many other insects (Lee, 2010), glycerol appears to be the main polyol

467 cryoprotectant associated with freeze tolerance in $C$. aeneicollis, although the accumulation (in

468 the region of tens of $\mathrm{mM}$ ) is relatively low compared to other cold-tolerant insects (e.g.

469 Crosthwaite et al., 2011; Kukal et al., 1988; Zachariassen, 1980). We detected hints of thermal

470 hysteresis activity in the hemolymph, suggesting that hemolymph antifreeze proteins play only a

471 small role in freeze tolerance in this species. Hemolymph osmolality nearly doubled between

472 summer and winter, although glycerol accumulation alone was not sufficient to explain this

473 osmolality increase. It is unlikely that the increased osmolality is due to inorganic ions

474 (Zachariassen et al., 2004). However, accumulation of the free amino acid proline has been

475 implicated in freeze tolerance for several insects (Koštál et al., 2012; Koštál et al., 2011; Ramløv,

476 1999) and plants (Nanjo et al., 1999), and could be a candidate to explain the additional

477 hemolymph osmolytes during winter.

479 Chrysomela aeneicollis adults are cold-hardy enough to survive winter temperatures in buffered

480 habitats, but our field observations and laboratory data suggest that late-instar larvae and pupae

481 are susceptible to cold snaps in late summer and early autumn. This could be a significant

482 selective pressure determining the developmental period of this species. In the context of climate

483 change, extreme events such as these are expected to increase in frequency, particularly in

484 conjunction with decreased precipitation (and therefore reduced snow cover buffering) in

485 California (Jayko and Millar, 2001; Pierce et al., 2008; Stewart et al., 2004). This means that 
486 even if mean temperatures are overall warmer, the poor survival of extreme events by pre-adult

487 life stages will likely reduce the possibility of changes in voltinism in response to extended

488 growing season. In turn, this will potentially exacerbate the impacts of energetic drain caused by

489 increased fall temperatures (Sinclair, in press; Williams et al., 2012). Thus, interactions between

490 development stage and cold hardiness have the potential to determine the effects of climate

491 change on univoltine montane species such as $C$. aeneicollis, the magnitude of which may be

492 determined by the intensity of metabolic suppression and extent of overwinter energetic drain.

493 There are well-established metabolism-related genetic polymorphisms in this species (Dahlhoff

494 et al., 2008; Dahlhoff and Rank, 2007; Rank et al., 2007; Wheat and Hill, 2014), and

495 investigating the influence of these on diapause and overwinter energetics may be crucial for

496 understanding the species' responses to climate change.

\section{5. Acknowledgements}

499 We thank two anonymous referees for their constructive comments, and Lauren Des Marteaux

500 for making glucose measurements. This work was supported by a Natural Science and

501 Engineering Research Council of Canada (NSERC) Discovery grant and a grant from the

502 Canadian Foundation for Innovation grant to BJS; a WMRS minigrant to ECB, and National

503 Science Foundation grant (DEB 0844404/06) to EPD, NER and JTS.

504

505 


\section{References}

Blakeney, A.B., Harris, P.J., Henry, R.J., Stone, B.A., 1983. A simple and rapid preparation of alditol acetates for monosaccharide analysis. Carbohydr. Res. 113, 291-299.

Brown, W.J., 1956. The New World Species of Chrysomela L. (Coleoptera: Chrysomelidae). Can. Entomol. 88 Supp. 3, 3-54.

Bruce, D.A., 2005. Effects of PGI genotype and temperature on fecundity, mating success and running speed of a Sierra willow leaf beetle. Sonoma State University, p. 39.

Creeden, E.P., Hicke, J.A., Buotte, P.C., 2014. Climate, weather, and recent mountain pine beetle outbreaks in the western United States. For. Ecol. Manage. 312, 239-251.

Crosthwaite, J.C., Sobek, S., Lyons, D.B., Bernards, M.A., Sinclair, B.J., 2011. The overwintering physiology of the emerald ash borer, Agrilus planipennis Fairmaire (Coleoptera: Buprestidae). J. Insect Physiol. 57, 166-173.

Dahlhoff, E.P., Fearnley, S.L., Bruce, D.A., Gibbs, A.G., Stoneking, R., McMillan, D.M., Deiner, K., Smiley, J.T., Rank, N.E., 2008. Effects of Temperature on Physiology and Reproductive Success of a Montane Leaf Beetle: Implications for Persistence of Native Populations Enduring Climate Change. Physiol. Biochem. Zool. 81, 718-732.

Dahlhoff, E.P., Rank, N.E., 2000. Functional and physiological consequences of genetic variation at phosphoglucose isomerase: Heat shock protein expression is related to enzyme genotype in a montane beetle. Proc. Natl. Acad. Sci. U. S. A. 97, 10056-10061.

Dahlhoff, E.P., Rank, N.E., 2007. The role of stress proteins in responses of a willow leaf beetle to environmental temperature variation. J. Biosci. 32, 477-488.

Dellicour, S., Fearnley, S., Lombal, A., Heidl, S., Dahlhoff, E.P., Rank, N.E., Mardulyn, P., 2014. Inferring the past and present connectivity across the range of a North American leaf beetle: Combining ecological niche modeling and a geographically explicit model of coalescence. Evolution 68, 2371-2385.

Edwards, J.S., 1986. How small ectotherms thrive in the cold without really trying. Cryo-Lett. 6, 388-390.

Gehrken, U., Southon, T.E., 1997. Effect of temperature on cold-hardiness and tissue ice formation in the adult chrysomelid beetle Melasoma collaris L. J. Insect Physiol. 43, 587593.

Gu, L., Hanson, P.J., Mac Post, W., Kaiser, D.P., Yang, B., Nemani, R., Pallardy, S.G., Meyers, T., 2008. The 2007 eastern US spring freezes: Increased cold damage in a warming world? Bioscience 58, 253-262.

Harrison, J.F., Woods, H.A., Roberts, S.P., 2012. Ecological and Environmental Physiology of Insects. Oxford, New York.

Irwin, J.T., Lee, R.E., 2003. Cold winter microenvironments conserve energy and improve overwintering survival and potential fecundity of the goldenrod gall fly, Eurosta solidaginis. Oikos 100, 71-78.

Jayko, A.S., Millar, C.I., 2001. Impacts of climate change on landscapes of the eastern Sierra Nevada and western Great Basin. U.S. Geological Survey, p. 35.

Kohshima, S., 1984. A novel cold-tolerant insect found in a Himalayan glacier. Nature 310, 225 227.

Koštál, V., Simek, P., Zahradnickova, H., Cimlova, J., Stetina, T., 2012. Conversion of the chill susceptible fruit fly larva (Drosophila melanogaster) to a freeze tolerant organism. Proc. Natl. Acad. Sci. U. S. A. 109, 3270-3274. 
Koštál, V., Zahradnickova, H., Simek, P., 2011. Hyperprolinemic larvae of the drosophilid fly, Chymomyza costata, survive cryopreservation in liquid nitrogen. Proc. Natl. Acad. Sci. USA 108, 13041-13046.

Kukal, O., Serianni, A.S., Duman, J.G., 1988. Glycerol metabolism in a freeze-tolerant arctic insect: an in vivo ${ }^{13} \mathrm{C}$ NMR study. J. Comp. Physiol. B 158, 175-183.

Lee, R.E., 2010. A primer on insect cold tolerance, in: Denlinger, D.L., Lee, R.E. (Eds.), Low Temperature Biology of Insects. Cambridge University Press, Cambridge, pp. 3-34.

Lee, R.E., Elnitsky, M.A., Rinehart, J.P., Hayward, S.A.L., Sandro, L.H., Denlinger, D.L., 2006. Rapid cold-hardening increases the freezing tolerance of the Antarctic midge Belgica antarctica. J. Exp. Biol. 209, 399-406.

Lee, R.E., Jr., Chen, C.-P., Denlinger, D.L., 1987. A rapid cold-hardening process in insects. Science 238, 1415-1417.

Lee, R.E., Jr., Costanzo, J.P., Kaufman, P.E., Lee, M.R., Wyman, J.A., 1994. Ice-nucleating active bacteria reduce the cold-hardiness of the freeze-intolerant Colorado Potato Beetle (Coleoptera: Chrysomelidae). J. Econ. Entomol. 87, 377-381.

MacMillan, H.A., Ferguson, L.V., Nicolai, A., Donini, A., Staples, J.F., Sinclair, B.J., 2015. Parallel ionoregulatory adjustments underlie phenotypic plasticity and evolution of Drosophila cold tolerance. J. Exp. Biol. 218, 423-432.

Marshall, K.E., Sinclair, B.J., 2010. Repeated stress exposure results in a survival-reproduction trade-off in Drosophila melanogaster. Proc. R. Soc. B 277, 963-969.

Marshall, K.E., Sinclair, B.J., 2012a. The impacts of repeated cold exposure on insects. J. Exp. Biol. 215, 1607-1613.

Marshall, K.E., Sinclair, B.J., 2012b. Threshold temperatures mediate the impact of reduced snow cover on overwintering freeze-tolerant caterpillars. Naturwissenschaften 99, 33-41.

McMillan, D.M., Fearnley, S.L., Rank, N.E., Dahlhoff, E.P., 2005. Natural temperature variation affects larval survival, development and Hsp70 expression in a leaf beetle. Funct. Ecol. $19,844-852$.

Nanjo, T., Kobayashi, M., Yoshiba, Y., Kakubari, Y., Yamaguchi-Shinozaki, K., Shinozaki, K., 1999. Antisense suppression of proline degradation improves tolerance to freezing and salinity in Arabidopsis thaliana. FEBS Lett. 461, 205-210.

Pierce, D.W., Barnett, T.P., Hidalgo, H.G., Das, T., Bonfils, C., Santer, B.D., Bala, G., Dettinger, M.D., Cayan, D.R., Mirin, A., Wood, A.W., Nozawa, T., 2008. Attribution of Declining Western US Snowpack to Human Effects. J. Clim. 21, 6425-6444.

R Core Team, 2012. R: A language and environment for statistical computing. R Foundation for Statistical Computing. www.R-project.org, Vienna.

Ramløv, H., 1999. Microclimate and variations in haemolymph composition in the freezingtolerant New Zealand alpine weta Hemideina maori Hutton (Orthoptera: Stenopelmatidae). J. Comp. Physiol. B 169, 224-235.

Ramløv, H., Bedford, J., Leader, J., 1992. Freezing tolerance of the New Zealand alpine weta, Hemideina maori Hutton (Orthoptera; Stenopelmatidae). J. Therm. Biol. 17, 51-54.

Rank, N.E., 1992a. A hierarchical analysis of genetic differentiation in a montane leaf beetle Chrysomela aeneicollis (Coleoptera, Chrysomelidae). Evolution 46, 1097-1111.

Rank, N.E., 1992b. Host plant preference based on salicylate chemistry in a willow leaf beetle (Chrysomela aeneicollis). Oecologia 90, 95-101.

Rank, N.E., 1994. Host plant effects on larval survival in a salicin-using leaf beetle Chrysomela aeneicollis Schaeffer (Coleoptera: Chrysomelidae). Oecologia 97, 342-353. 
Rank, N.E., Bruce, D.A., McMillan, D.M., Barclay, C., Dahlhoff, E.P., 2007. Phosphoglucose isomerase genotype affects running speed and heat shock protein expression after exposure to extreme temperatures in a montane willow beetle. J. Exp. Biol. 210, 750-764.

Ring, R.A., 1982. Freezing-tolerant insects with low supercooling points. Comp. Biochem. Physiol. 73A, 605-612.

Sformo, T., Kohl, F., McIntyre, J., Kerr, P., Duman, J.G., Barnes, B.M., 2009. Simultaneous freeze tolerance and avoidance in individual fungus gnats, Exechia nugatoria. J. Comp. Physiol. B 179, 897-902.

Sinclair, B., Vernon, P., Klok, C., Chown, S., 2003. Insects at low temperatures: an ecological perspective. Trends Ecol. Evol. 18, 257-262.

Sinclair, B.J., 1997. Seasonal variation in freezing tolerance of the New Zealand alpine cockroach Celatoblatta quinquemaculata. Ecol. Entomol. 22, 462-467.

Sinclair, B.J., 1999. Insect cold tolerance: How many kinds of frozen? Eur J Entomol 96, 157164.

Sinclair, B.J., 2001a. Biologically relevant environmental data: Macros to make the most of microclimate recordings. Cryo-Lett. 22, 125-134.

Sinclair, B.J., 2001b. Field ecology of freeze tolerance: interannual variation in cooling rates, freeze-thaw and thermal stress in the microhabitat of the alpine cockroach Celatoblatta quinquemaculata. Oikos 93, 286-293.

Sinclair, B.J., in press. Linking energetics and overwintering in temperate insects. J. Therm. Biol. Sinclair, B.J., Chown, S.L., 2002. Haemolymph osmolality and thermal hysteresis activity in 17 species of arthropods from sub-Antarctic Marion Island. Polar Biol. 25, 928-933.

Sinclair, B.J., Chown, S.L., 2005. Climatic variability and hemispheric differences in insect cold tolerance: support from southern Africa. Funct. Ecol. 19, 214-221.

Sinclair, B.J., Chown, S.L., 2010. The macrophysiology of insect thermal limits, in: Denlinger, D.L., Lee, R.E. (Eds.), Insect Low Temperature Biology. Cambridge University Press, Cambridge, pp. 191-223.

Sinclair, B.J., Gibbs, A.G., Lee, W.K., Rajamohan, A., Roberts, S.P., Socha, J.J., 2009. Synchrotron X-Ray Visualisation of Ice Formation in Insects during Lethal and NonLethal Freezing. Plos One 4, e8259.

Smiley, J.T., Rank, N.E., 1986. Predator protection versus rapid growth in a montane leaf beetle. Oecologia 70, 106-112.

Sømme, L., 1989. Adaptations of terrestrial insects to the alpine environment. Biol. Rev. 64, 367-407.

Sømme, L., 1995. Invertebrates in Hot and Cold Arid Environments. Springer-Verlag, Berlin.

Sømme, L., Davidson, R.L., Onore, G., 1996. Adaptations of insects at high altitudes of Chimborazo, Ecuador. Eur. J. Entomol. 93, 313-318.

Stewart, I.T., Cayan, D.R., Dettinger, M.D., 2004. Changes in snowmelt runoff timing in western North America under a 'business as usual' climate change scenario. Clim. Change 62, 217-232.

Storey, J.M., Storey, K.B., 1983. Regulation of cryoprotectant metabolism in the overwintering gall fly larva, Eurosta solidaginis - Temperature control of glycerol and sorbitol levels. J. Comp. Physiol. 149, 495-502.

Udaka, H., Sinclair, B.J., 2014. The overwintering biology of the acorn weevil, Curculio glandium in southwestern Ontario. J. Therm. Biol. 44, 103-109. 
Voituron, Y., Mouquet, N., de Mazancourt, C., Clobert, J., 2002. To freeze or not to freeze? An evolutionary perspective on the cold-hardiness strategies of overwintering ectotherms. Am. Nat. 160, 255-270.

Vrba, P., Konvicka, M., Nedved, O., 2012. Reverse altitudinal cline in cold-hardiness among Erebia butterflies. CryoLetters 33, 251-258.

Walters, K.R., Serianni, A.S., Voituron, Y., Sformo, T., Barnes, B.M., Duman, J.G., 2011. A thermal hysteresis-producing xylomannan glycolipid antifreeze associated with cold tolerance is found in diverse taxa. J. Comp. Physiol. B 181, 631-640.

Watanabe, M., Tanaka, K., 1998. Adult diapause and cold hardiness in Aulacophora nigripennis (Coleoptera : Chrysomelidae). 44, 1103-1110.

Watanabe, M., Tanaka, K., 1999. Cold tolerance strategy of the freeze-intolerant chrysomelid, Aulacophora nigripennis (Coleoptera : Chrysomelidae), in warm- temperate regions. Eur. J. Entomol. 96, 175-181.

Wharton, D.A., 2011. Cold tolerance of New Zealand alpine insects. J. Insect Physiol. 57, 10901095.

Wheat, C.W., Hill, J., 2014. Pgi: the ongoing saga of a candidate gene. Curr. Opinion Insect Sci. 4, 42-47.

Williams, C.M., Henry, H.A.L., Sinclair, B.J., 2015. Cold truths: how winter drives responses of terrestrial organisms to climate change. Biol. Rev. 90, 214-235.

Williams, C.M., Marshall, K.E., Macmillan, H.A., Dzurisin, J.D.K., Hellmann, J.J., Sinclair, B.J., 2012. Thermal variability increases the impact of autumnal warming and drives metabolic suppression in an overwintering butterfly. Plos One 7, e34470.

Zachariassen, K.E., 1980. The Role of Polyols and Nucleating-Agents in Cold-Hardy Beetles. J. Comp. Physiol. 140, 227-234.

Zachariassen, K.E., 1985. Physiology of cold tolerance in insects. Physiol. Rev. 65, 799-832.

Zachariassen, K.E., Kristiansen, E., 2000. Ice nucleation and antinucleation in nature. Cryobiol. 41, 257-279.

Zachariassen, K.E., Kristiansen, E., Pedersen, S.A., 2004. Inorganic ions in cold-hardiness. Cryobiol. 48, 126-133.

Zachariassen, K.E., Li, N.G., Laugsand, A.E., Kristiansen, E., Pedersen, S.A., 2008. Is the strategy for cold hardiness in insects determined by their water balance? A study on two closely related families of beetles: Cerambycidae and Chrysomelidae. J. Comp. Physiol. B 178, 977-984.

Zettel, J., Zettel, U., 1994. Adaptations to the Alpine environment in Isotomurus alticola (Collembola: Isotomidae) in the Swiss Alps. Acta Oecologica 15, 93-104. 


\section{Figure Captions}

679 Figure 1 - Single (A) and double (B) exotherms observed in pupae of C. aeneicollis.

Figure 2 - Gravimetric water content (A), glycerol content (B) and estimated hemolymph

681 glycerol concentration (see text for details of estimation) in all life stages of C. aeneicollis.

682 'First', 'Second' and 'Third' refer to larval instars. Mean \pm SEM presented; values with differing 683 letters are significantly different within a panel.

684

685

686

687

688

689

690

691

692

693

694

695

696

697

698
Figure 3 - Sample gas chromatography traces of polyols and carbohydrates in (A) summer and

(B) quiescent adult C. aeneicollis beetles. Carbohydrates were analysed as their acetylated polyol derivatives (see text for details). RP: Reagent peak.

Figure 4 - Sample microclimate temperatures from different microhabitats (A-C) and elevations (D-F) inhabited by $C$. aeneicollis beetles in the Big Pine Creek (BPC) catchment. Three different microsites (A: within the willow canopy; B: in leaf litter at the base of the willow; and C: c. $3 \mathrm{~cm}$ below the soil surface) at $3353 \mathrm{~m}$. Temperatures within the willow canopy, where beetles are active during the day in summer, are also shown for willows at 3215, 2905 and $2773 \mathrm{~m}$ are shown (see also Table 1); note that the willows may collapse under the weight of snow, reducing the height above the ground in the winter. Horizontal dashed line indicates $0{ }^{\circ} \mathrm{C}$. Periods with little daily variance are likely due to temperatures being buffered by snow cover (see also Supplementary Material Figure S1).

Figure 5 - Mean minimum temperature at three microhabitats for (A) $3553 \mathrm{~m}$ and (B) $2770 \mathrm{~m}$ sites in the Big Pine Creek catchment over the duration of each life stage of the beetle $C$. aeneicollis (median lethal temperatures shown for comparison with the exception of quiescent 
699 adults, for which the lowest temperature for which survival was observed $\left(-10^{\circ} \mathrm{C}\right)$ is plotted

700 without error bars, see text for details). See Table 1 for timespan of temperature measurements.

701 
702 Table 1. Microclimate temperature monitoring sites in the Big Pine Creek drainage of the Sierra

703 Nevada Mountains, California. Microclimate temperatures were recorded every 30 min at c. 1.2

$704 \mathrm{~m}$ height in the willow canopy (2005-2011), and at the base of the stem and buried c. $5 \mathrm{~cm}$ in the

705 soil (2009-2011). All logger data recordings completed in June of 2012 unless noted.

\begin{tabular}{lcccc}
\hline Site & Altitude & Coordinates & $\begin{array}{c}\text { Initiation of mid- } \\
\text { willow logging }\end{array}$ & $\begin{array}{c}\text { Initiation of } \\
\text { other logging }\end{array}$ \\
\hline Sam Mac Meadow & $3353 \mathrm{~m}$ & $37.119^{\circ} \mathrm{N} 118.506^{\circ} \mathrm{W}$ & July 2005 & June 2009 \\
Upper Site & $3215 \mathrm{~m}$ & $37.124^{\circ} \mathrm{N} 118.502^{\circ} \mathrm{W}$ & June 2000 & June 2009 \\
$40 \mathrm{Bog}$ & $2905 \mathrm{~m}$ & $37.132^{\circ} \mathrm{N} 118.473^{\circ} \mathrm{W}$ & August 2000 & June $2009^{*}$ \\
$26 \mathrm{Bog}$ & $2773 \mathrm{~m}$ & $37.137^{\circ} \mathrm{N} 118.463^{\circ} \mathrm{W}$ & August 2000 & June 2009 \\
\hline
\end{tabular}

706 *Recording ended 2011 at base of willow at this site. 
707 Table 2. Mortality of each life stage of Chrysomela aeneicollis after $1 \mathrm{~h}$ cold exposure with and 708 without internal ice formation, yielding cold tolerance strategy. These data represent an 709 aggregate of all experiments in which ice formation was recorded in some beetles.

\begin{tabular}{lcccc}
\hline Life Stage & $\begin{array}{c}\text { Died without } \\
\text { internal ice } \\
\text { formation }\end{array}$ & $\begin{array}{c}\text { Died after } \\
\text { internal ice } \\
\text { formation }\end{array}$ & $\mathbf{N}$ & $\begin{array}{c}\text { Cold tolerance } \\
\text { strategy }\end{array}$ \\
\hline Egg & 0 & 72 & 72 & Freeze Avoidant
\end{tabular}

\section{Larvae}

First Instar 44

Second Instar

40

44

44

Chill Susceptible

Third Instar

57

40

40

Chill Susceptible

Third Instar

0

57

57

Chill Susceptible

Pupa

61

66

Freeze Avoidant

Adult

Quiescent

0

0

30

Freeze Tolerant

Summer-collected

0

3

264

Freeze Tolerant 
711 Table 3. Mean $\left( \pm\right.$ SEM) supercooling point and median lethal temperature $\left(\mathrm{LT}_{50}\right)$ for each life

712 stage of Chrysomela aeneicollis. Similar superscript letters indicate no significant difference

713 between the supercooling points $(\mathrm{p}<0.001)$; sample size for SCP is in parentheses. The $\mathrm{LT}_{5}$ and

$714 \mathrm{LT}_{95}$ are given in parentheses after $\mathrm{LT}_{50}$; different superscript letters indicate values for which

715 this range does not overlap. Note that the lowest temperature survived by an individual quiescent

716 beetle was $-10^{\circ} \mathrm{C}$, and we use that estimate in subsequent analyses.

\begin{tabular}{lcc}
\hline Life stage & $\begin{array}{c}\text { Supercooling } \\
\text { point }\left({ }^{\circ} \mathbf{C}\right)\end{array}$ & LT50 (LT5, LT95) \\
\hline Egg & $-23.4 \pm 0.18^{\mathrm{b}}(47)$ & $-20.1(-19.3,-20.8)^{\mathrm{s}}$ \\
First Instar Larva & $-10.6 \pm 0.47^{\mathrm{c}}(22)$ & $-3.2(-0.3,-6.8)^{\mathrm{q}}$ \\
Second Instar Larva & $-10.8 \pm 0.68^{\mathrm{c}}(16)$ & $-6.2(-1.5,-11.0)^{\mathrm{pq}}$ \\
Third Instar Larva & $-8.6 \pm 0.62^{\mathrm{c}}(32)$ & $-8.7(-8.3,-9.1)^{\mathrm{p}}$ \\
Pupa & $-11.1 \pm 1.14^{\mathrm{cd}}(6)$ & $-11.4(-4.5,-18.2)^{\mathrm{pqr}}$ \\
Single Exotherm & $-13.6 \pm 0.05^{\mathrm{de}}(18)$ & \\
Double exotherm & $-17.5 \pm 0.75^{\mathrm{e}}(18)$ & \\
First Exotherm & $-4.9 \pm 0.05^{\mathrm{a}}(95)$ & $-9.2(-8.8,-9.6)^{\mathrm{p}}$ \\
Second Exotherm & $-5.3 \pm 0.11^{\mathrm{a}}(28)$ & $-15.0(-14.4,-15.6)^{\mathrm{r}}$ \\
Summer Adult & & \\
Quiescent Adult & & \\
\hline
\end{tabular}




\section{FigXUN}

Fig 1
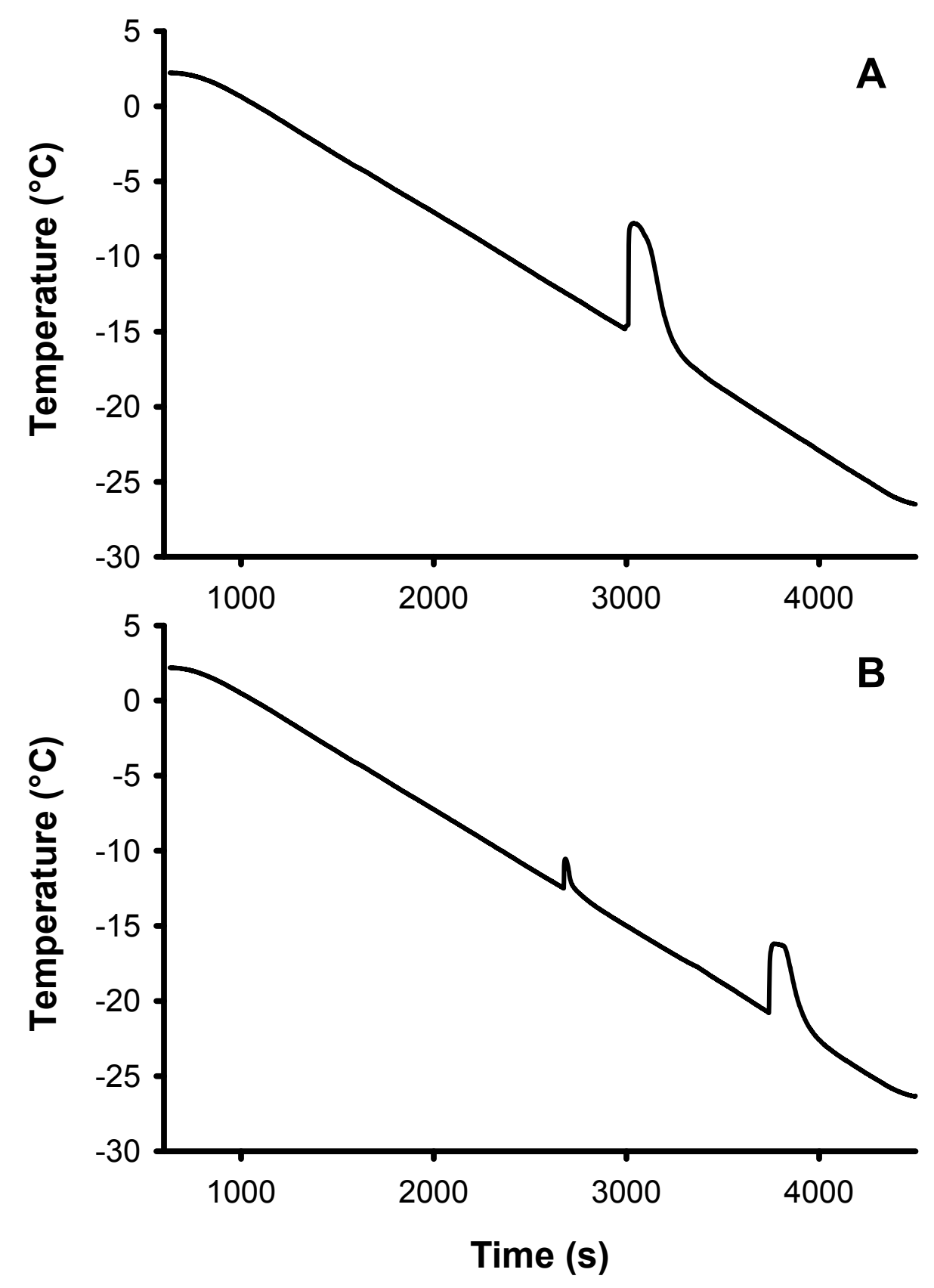

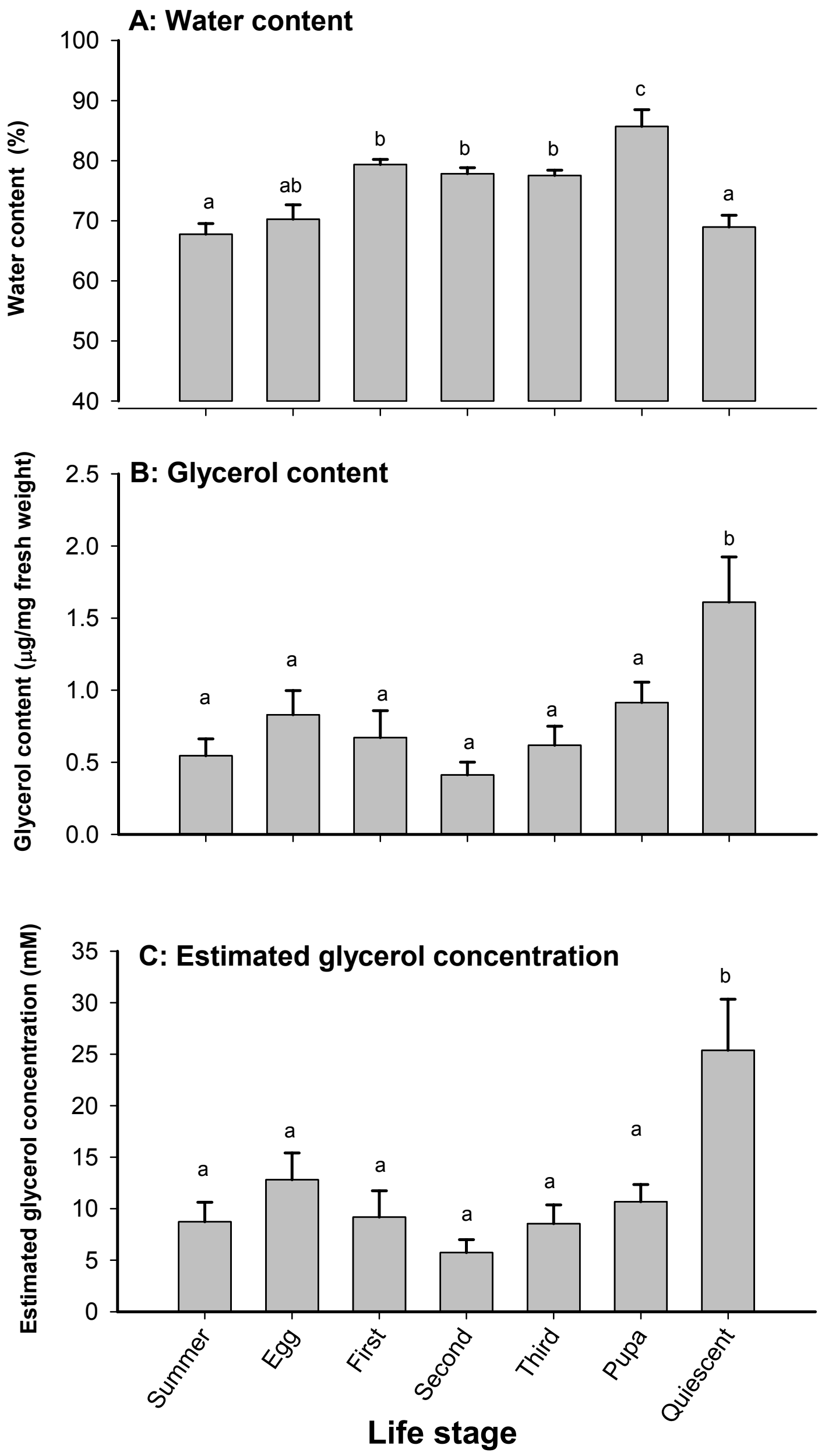


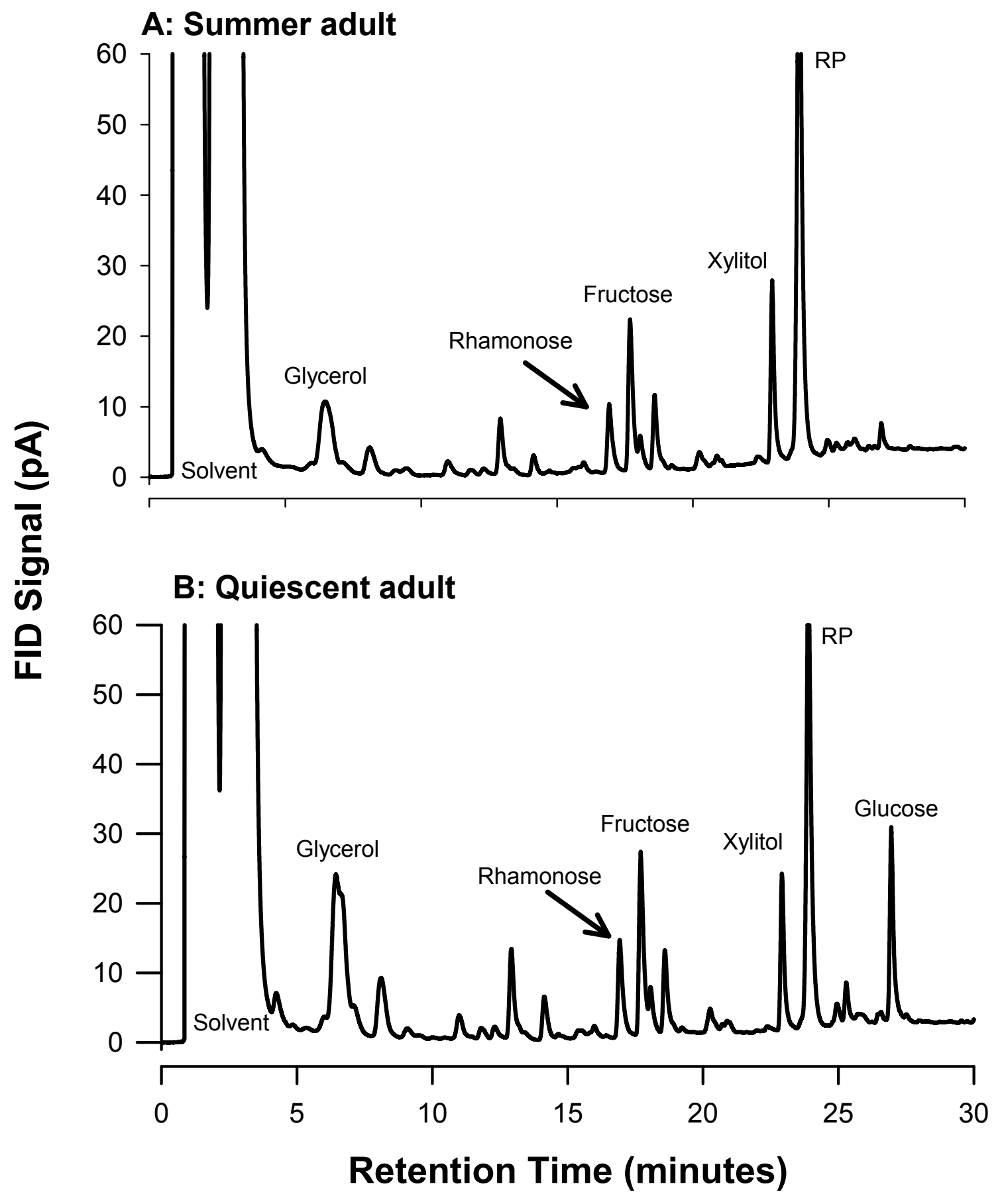


A: Mid-Willow, 3353 m

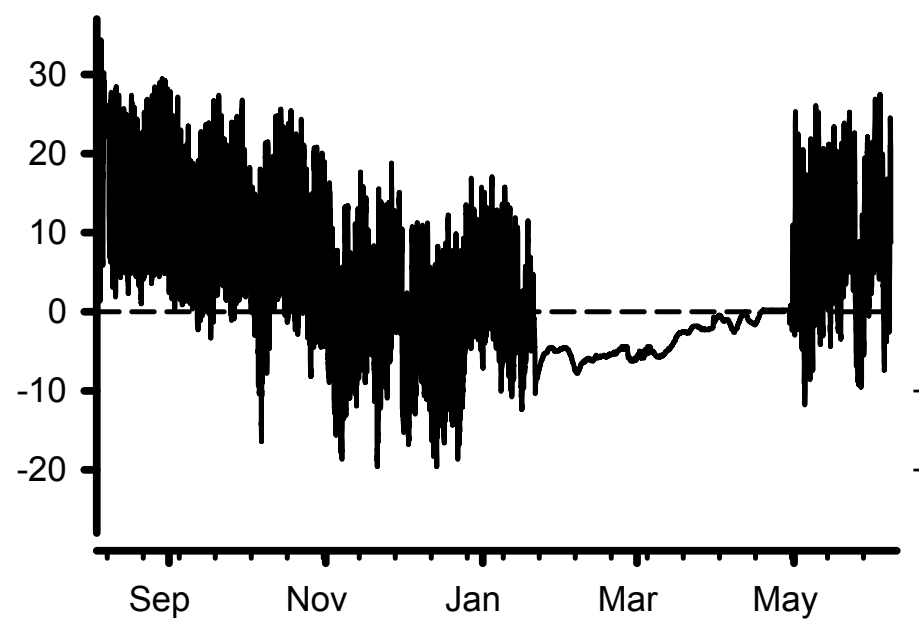

B: Base of Willow, 3353 m
D: Mid-Willow, 3215 m

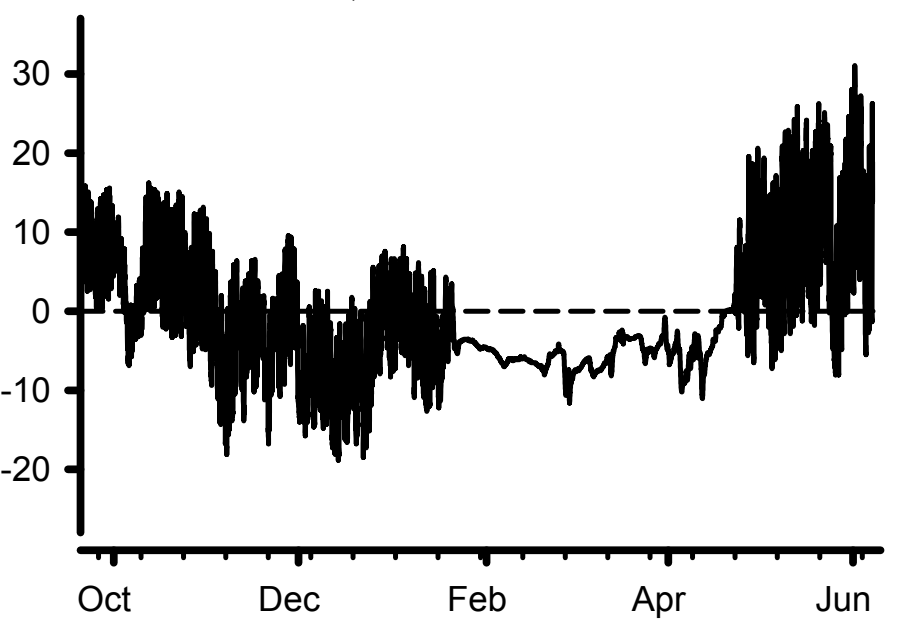

E: Mid-willow, 2905 m
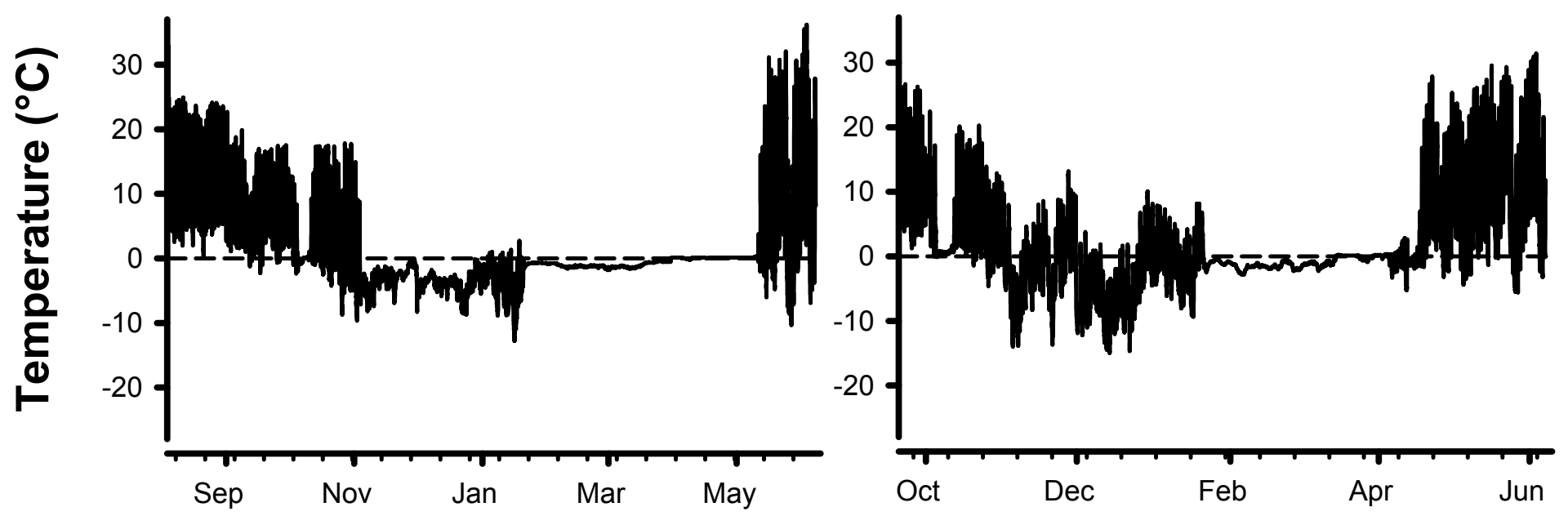

C: Soil, 3353 m

F: Mid-willow, 2773 m
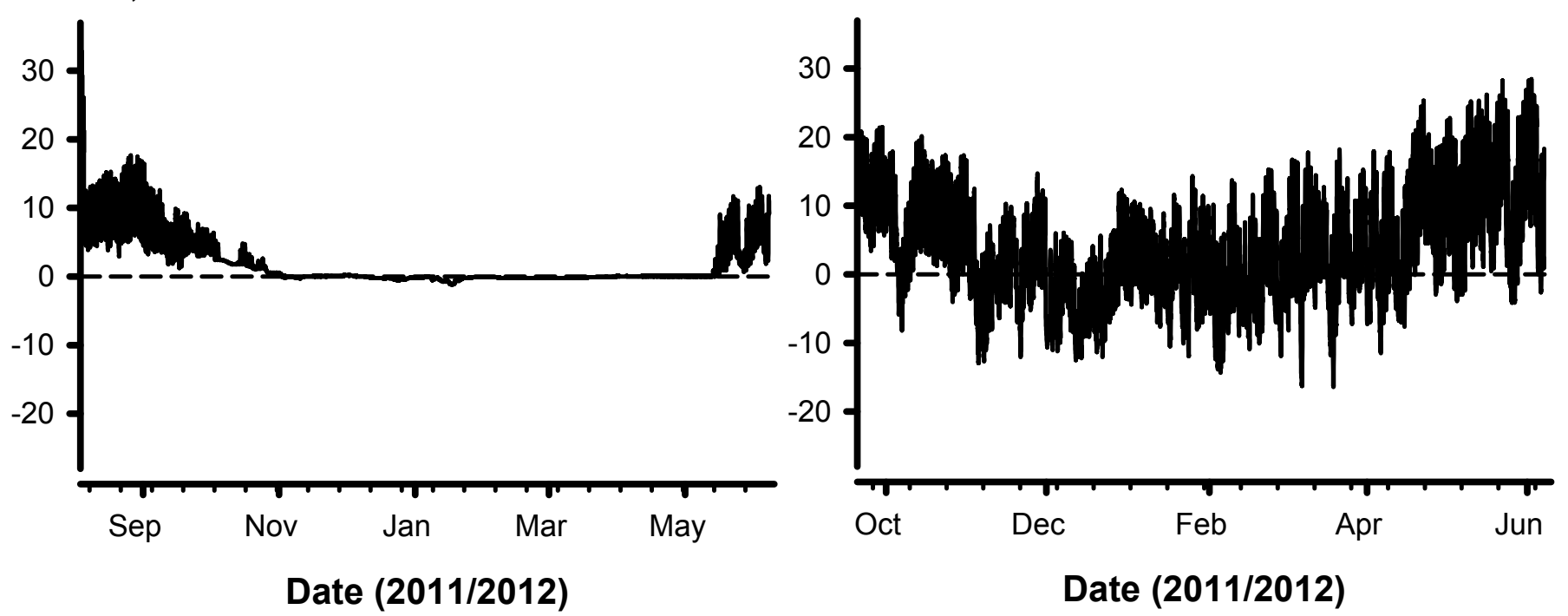

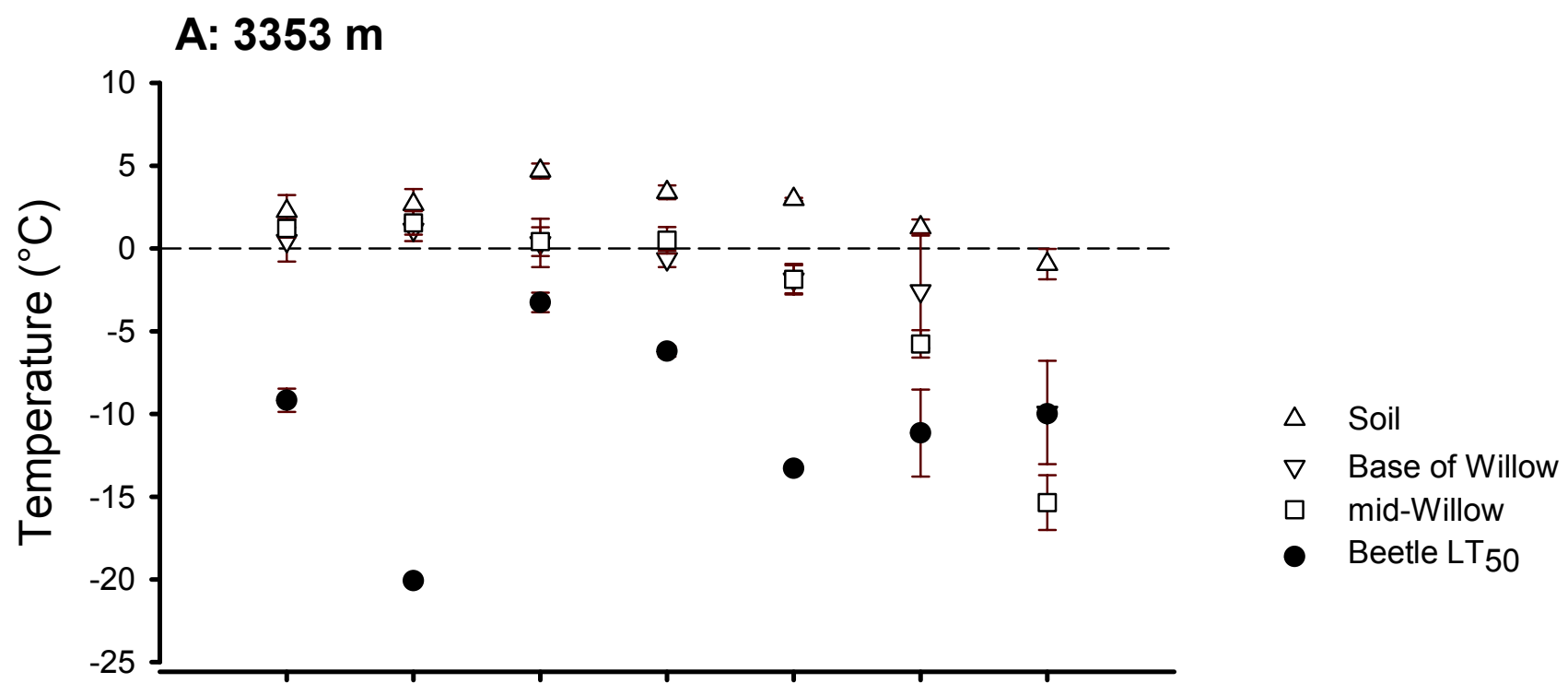

B: $\mathbf{2 7 7 0 ~ m ~}$

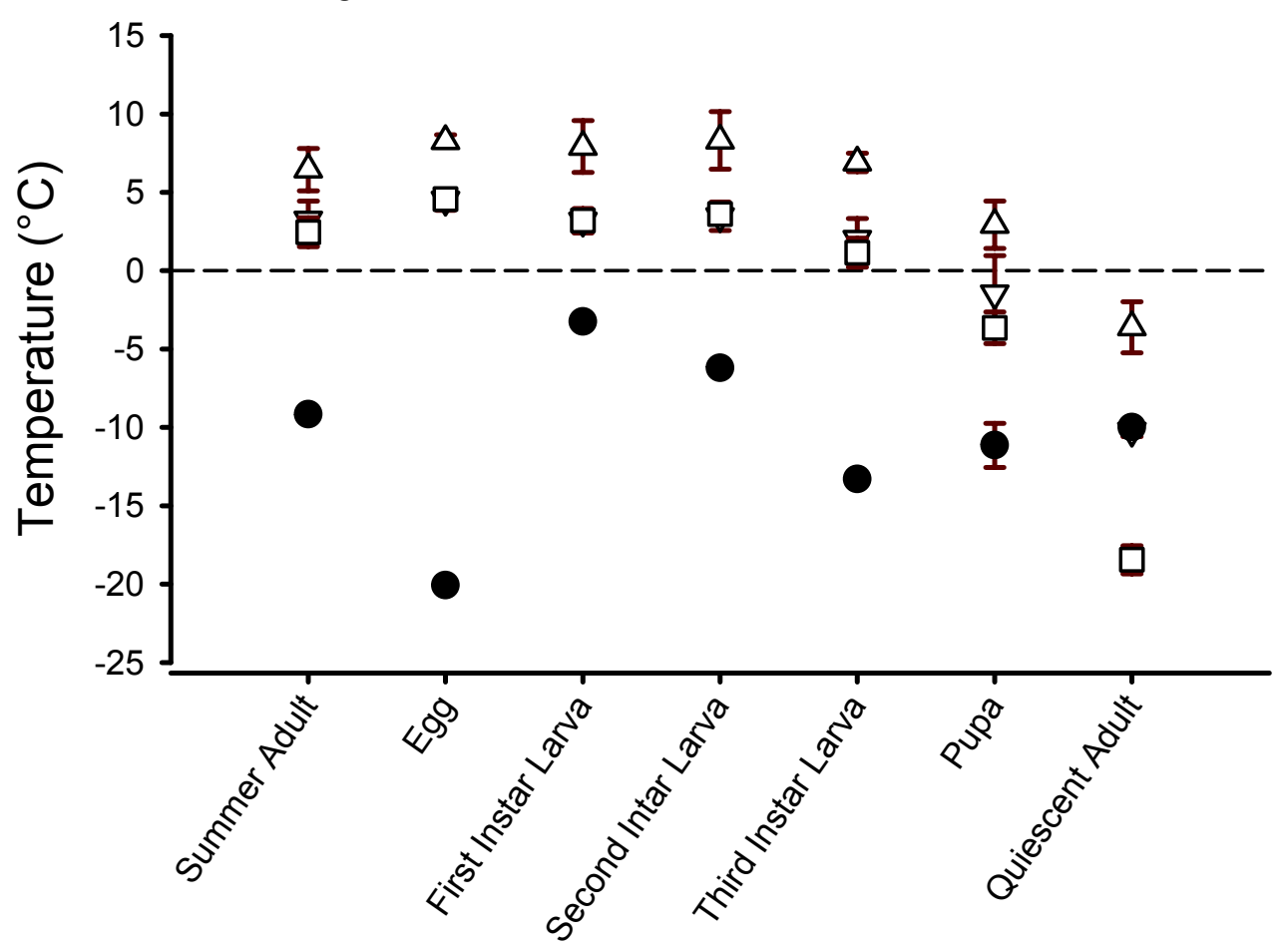

Life stage 


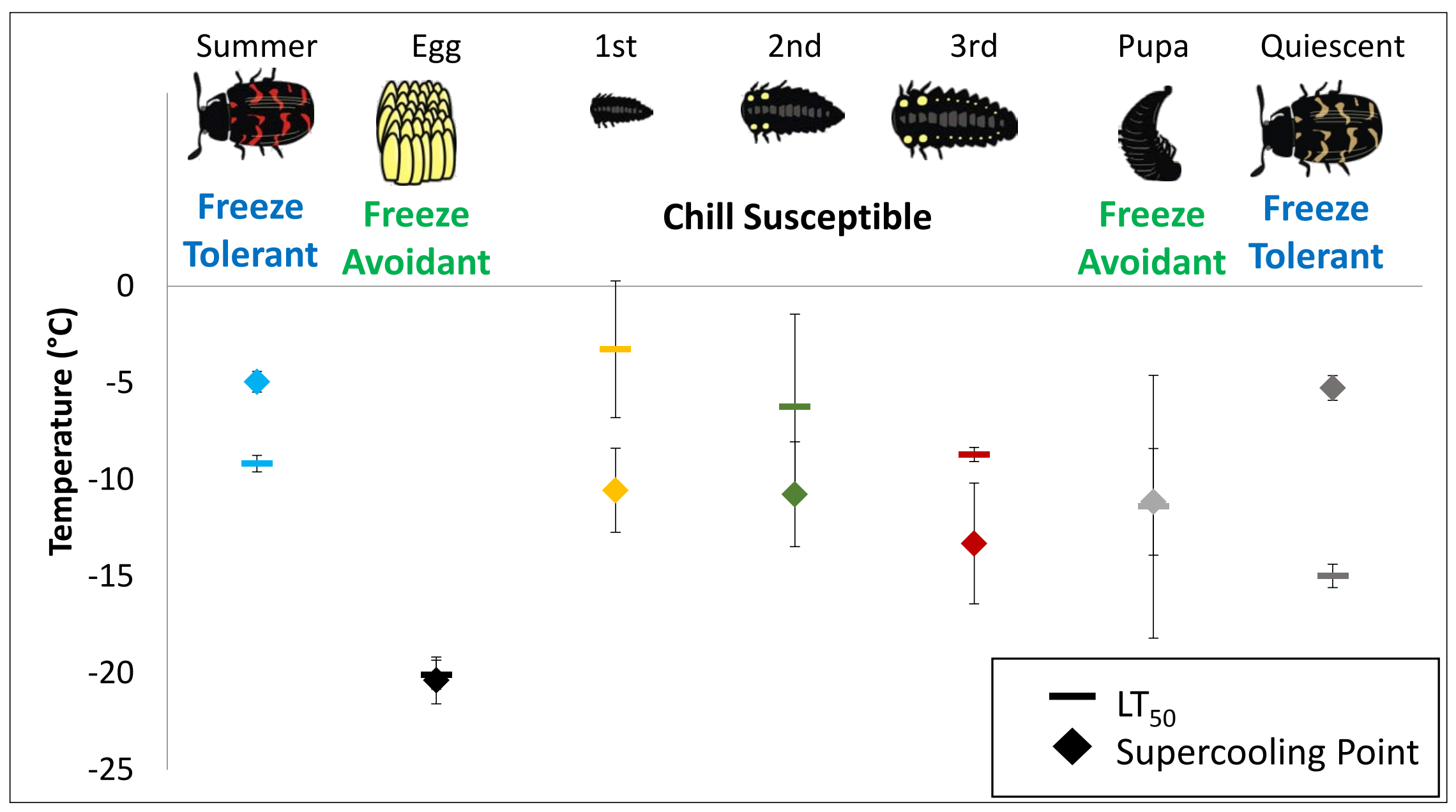

